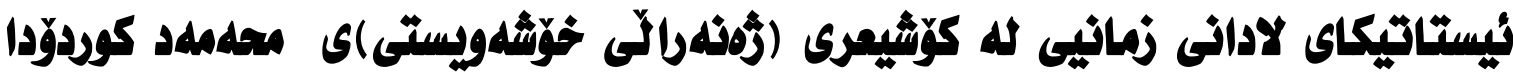

\section{ئاسوّ عومهر مستهفا}

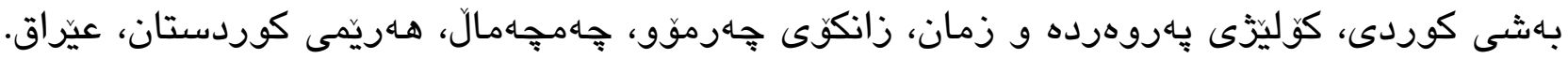
ئيمهيل: aso.omar@charmouniversity.org

ئيستاتيكا رهكهزيكى سهرهكى شيعره، بهدريّزايى ميّزوو شاعيران كرنكيان بهم رهكازه داوه و لهيَيناو

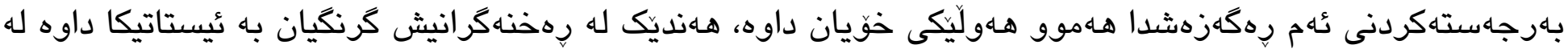

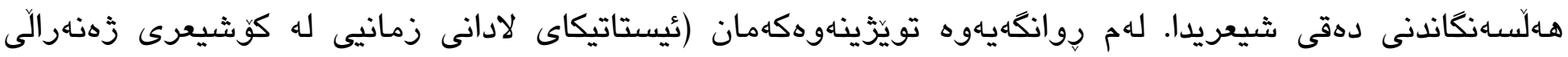

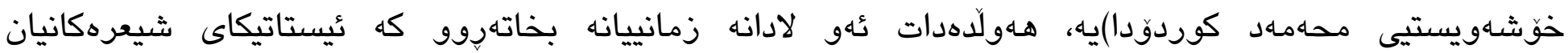
بهارجتهكردووه.

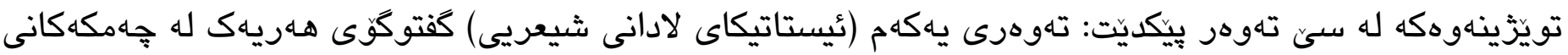
شيعر و زمان و لادان و وِايوهندييان به بيكهينانى ئيستاتيكاى دهقهوه دهكات. تهوهرى دووهم (ئيستاتيكاى ناونيشان)

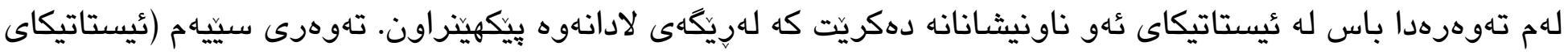

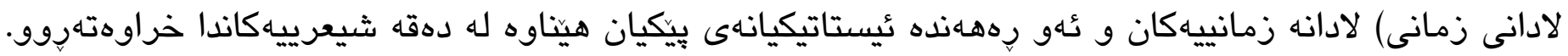
ئهنجامهكانيش له كوتاييدا به جְهند خاليّك خراونهتهروو، له كَل ليستى سهرجاوهكان كليله وشهكان: ئيستاتيكا، جوانى، لادان، لادانى زمانى، لادانى وشهيى، لابردن. 


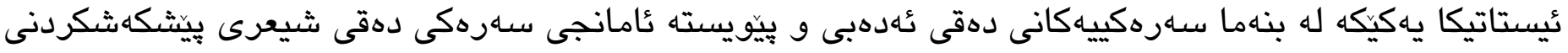

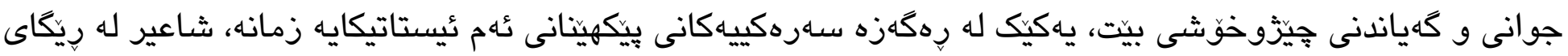

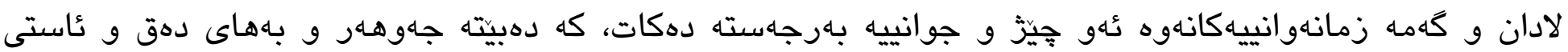
هونهرى دهقهك بهرز دهكاتهوه. لهم روانكَهيهوه كه تويّزينهوهكهان به ناونيشانى (ئيستاتيكاى لادانى زمانيى له

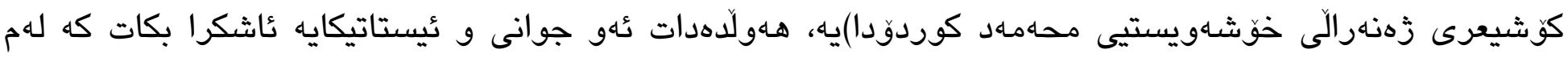

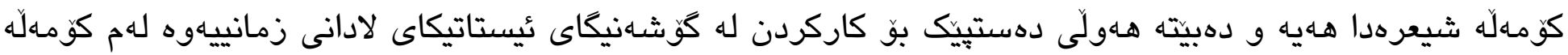

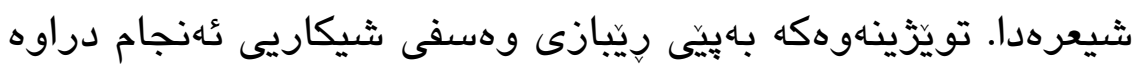

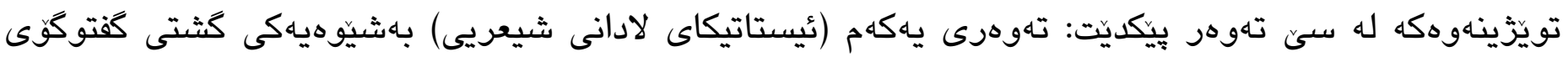
هـريـك له جهامكهكانى ثيعر و ئيستاتيكا و زمان و لادان و پيهيوهندييان به يِيكهينانى ئيستاتيكاى دهقهوه دهكات. تهوهرى دووهم (ئيستاتيكاى ناونيشان) لهم تهوهرهدا باس له نيستاتيكاى ئهو ناونيشـانانه دهكريت كه لهريّكاهى لادانهوه

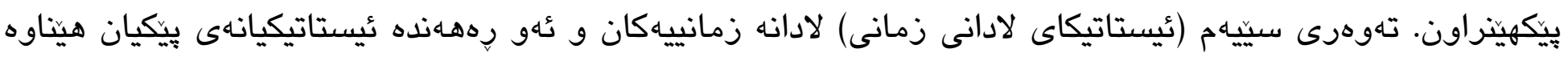
له دهقه شيعرييهكاندا خراوهتهروو. لئرون.

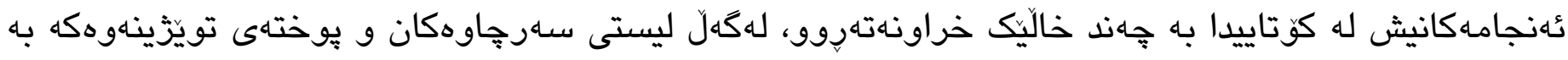
زمانهكانى كوردى و عارهبى و كينگليزى.

\section{تلوورى يلكdم (ئيستاتيكاى لاداثى شيعريق)}

شيعر لادانه له باو، لادانه له زمانى عاسايى. شاعير دهبيت جيهانبينييهكى فراوانى هـبيتيت و له كُوشـهنيكايهكى جياوازهوه زيان بيينيت و كُوزارشتى لكى بكات، شيعر دهبى شتى تازه و نويّمان بيى ببهخشيت، تا بتوانيت له هزر و

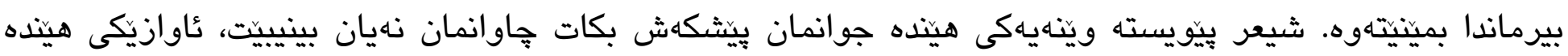

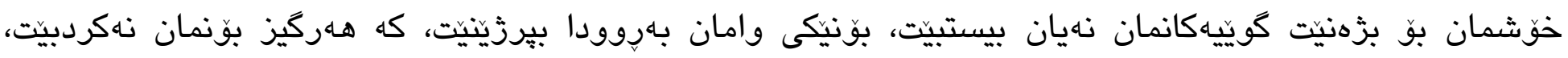

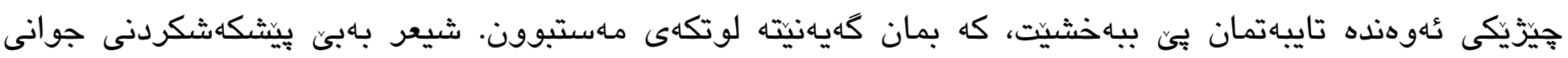

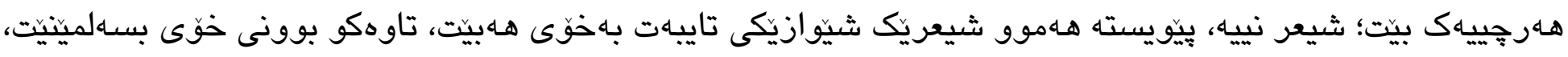
ئيستاتيكايهكى وههاى تيّابيت نهمريى بينى ببهخشيت.

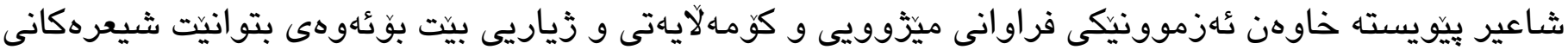
بـاهيّوهياكى هونهريى جوان يِيشكهش بـه يهياموهركران بكات، جونكه ناكريّت ئهزموونى ئهدهبى شـاعير له سنوورى

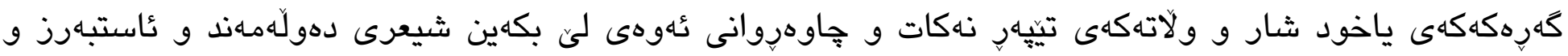


ئيستاتيكيمان يِيشكهش بكات. شيعرى ساكار كه تهنها رِووكهشى شتهكانمان بو دهكويّزيتهوه، رِووناكيى و بوّن و

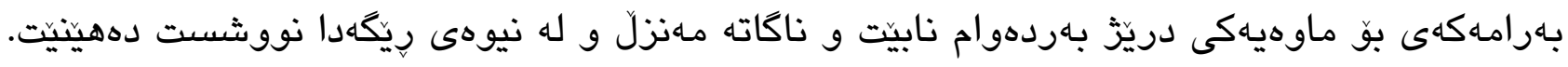

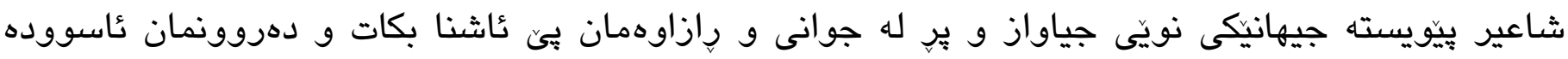
بكات. يهكيك له رههـانده كرنكاهكانى ئهم جوانى و ئيستاتيكايه لادانه، بهتايبهتى لادانى زمانيى، شـاعير دهبيت مامـلّهيهكى

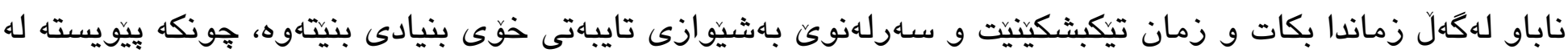

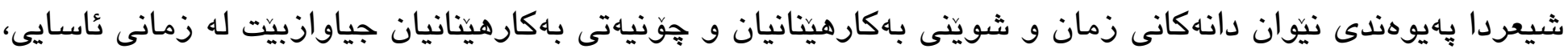

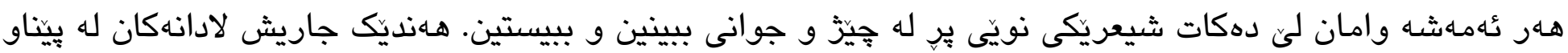

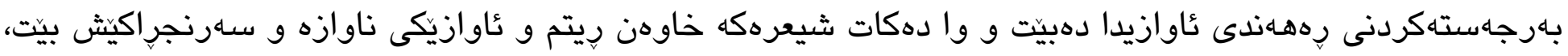

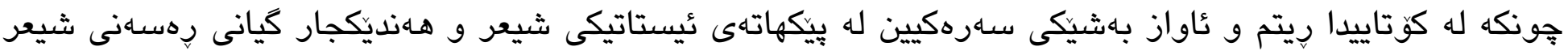

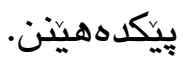

دهقى نهمر و زيندوو ئهو دهقهيه له يِيشكهشكردنى جوانى و ئيستاتيكادا له لوتكهدا بيت و خاوهنى لادانهكان

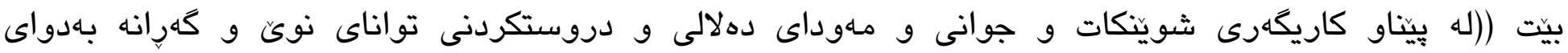

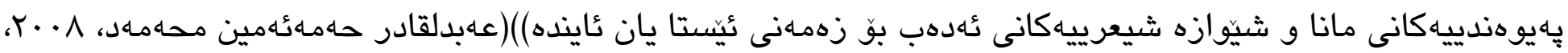

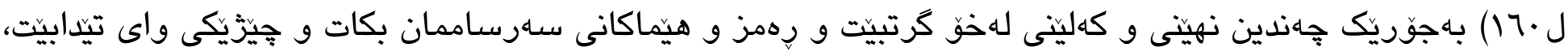
كه سنوور و سـردهمهكان بِرِيت و جوانى و رِازاوهييهكهى للدهست نهدات.

لادان بهكارهينانيكى داهيناهرانهى زمانه و دهبيته هوَى دهولَهماندبوونى زمانى شيعر و باركاويكردنى بهُهـندين

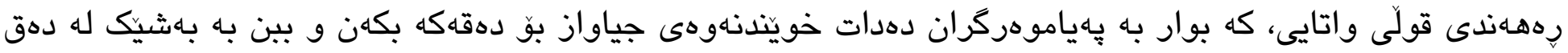

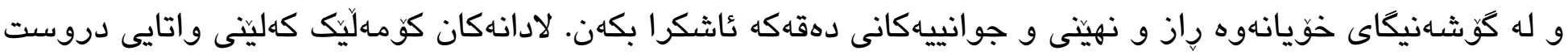

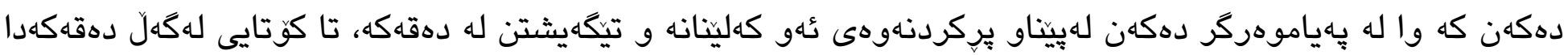

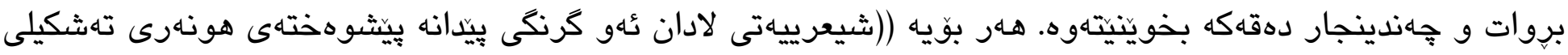

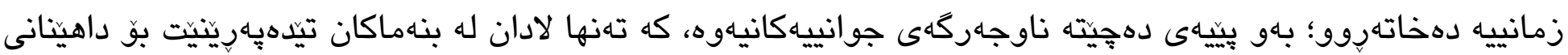

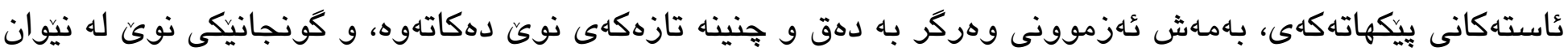
وشهان دروست دهكات و دهيكوازيتهاهه له سياقيكى بيّكهاتهيى باو (مألوف)هوه بو سياقيكى جياواز، كه تيّيدا دووباره

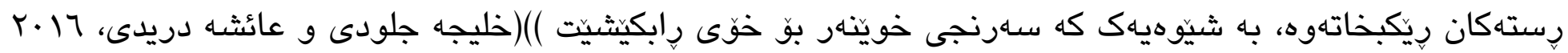

(KY.

زمان لهشيعرى نويّدا دهبيت يِيِيت له لادان و هونهركاريى و جياوازبيت له زمانى عاسـايى. زمانى شيعريى

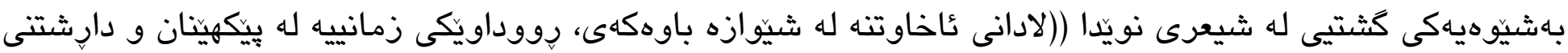


ئاخاوتتدا دهردهكهيّت، كه دهتوانين بههوَيهوه سروشتى شيّوازى ئهدهبى بناسينهوه، تهنانهت دهتوانين لادان به خودى

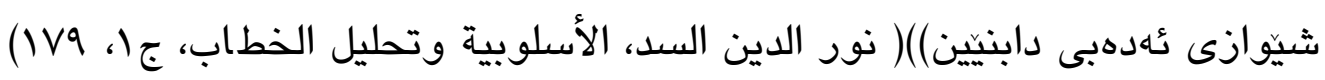
لادانى زمانى رهكازى سـرهكيى جياكهرهوهى نيّوان زمانى عاخاوتنى عاسايى خهلك و زمانى شيعرييه، جونكه ((ريّزمان ياساكانى زمان ريّكدهات و زانستى شيّوازيش [لادان] تواناكانى زمانى و ياسـاكانى دهستهبهردهكات و

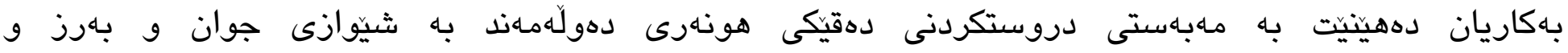

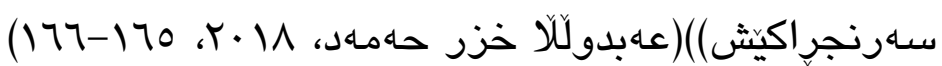

\section{تلوهرى دووهم (نيستاتيكاى ناونيشان)}

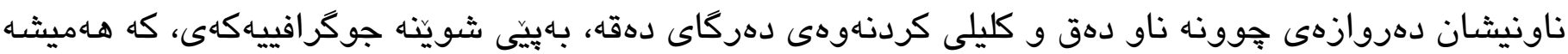

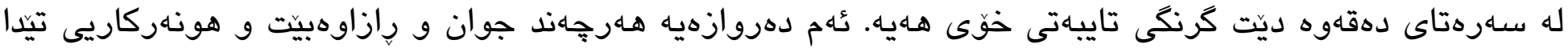
ئهنجام درابيت، ئهوهنده زياتر دهبيته هوَى رِاكيثانى سهرنجى خويّنهر و هانى دهدات بو خويندنهوهى دهقهك. له

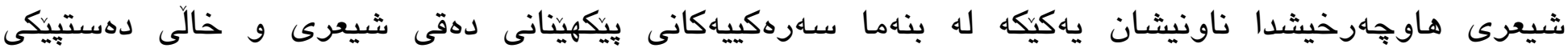

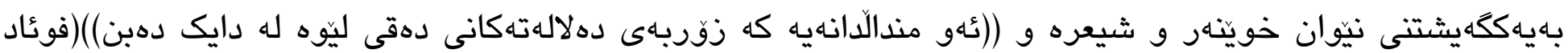

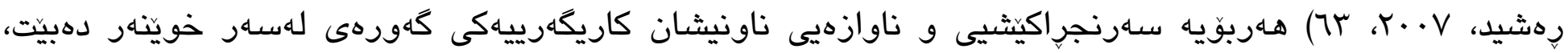

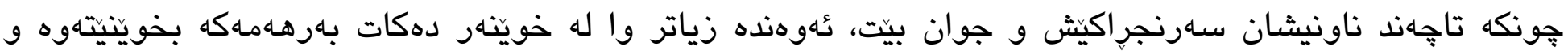
لهكَّلى بـهردهوام بيّت

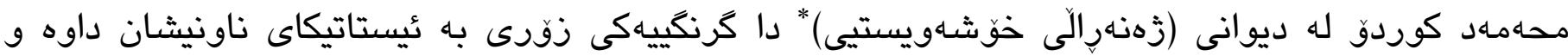

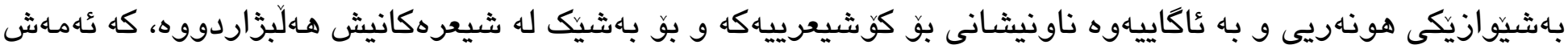

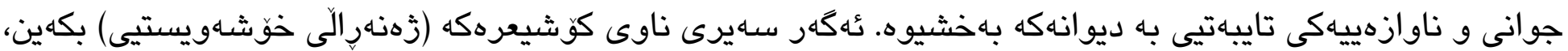

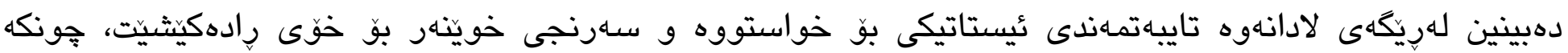

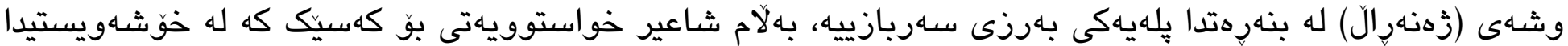
قال بووهتهوه و سهرجهم پِلهكانى عيشقى بريوه، تا كَهيشتوه بهم پِله بهرزه. هـروهها به نادياريش هاتووه، واتا دهشيت تئه كهسه من يان تق يان شـاعير ياخود هـهر كهينيك بيت، كه ئهو ئهزموونهى تاقيكردبيتهوه، بهمهاش لادانيكى

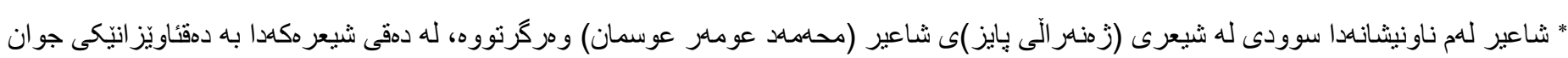

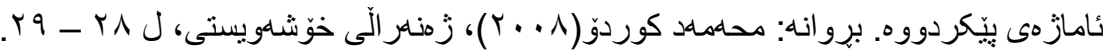


واتايى جوانى دروستكردووه و ناونيشانهكهشى جوانتر و سهرنجراكيش كردووه. لهكَلّ ثُهوهشدا رههـنديَكى موّسيقيى به ناونيشانهكه بهخشيووه، كه تُهمه شئوهندهى تر داهينانى ناونيشانهكهى هونهريانه كردووه.

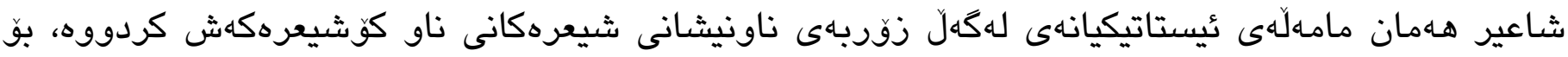

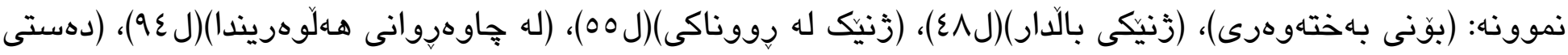

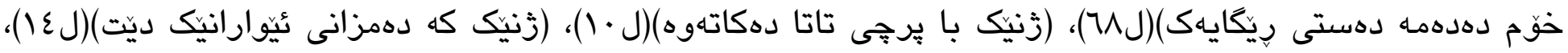

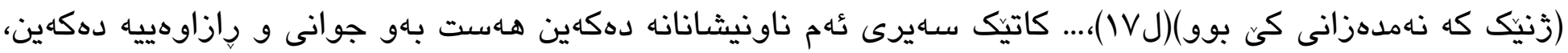

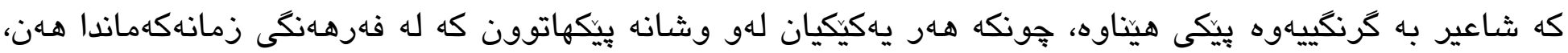

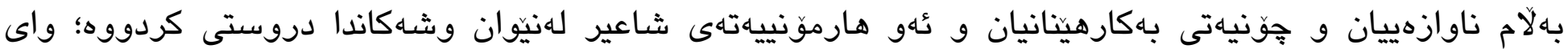
كردووه رههـنديكى ئيستاتيكى و واتايى قوول ببهخشن و سـرنجى يهاياموهركران بوّ خوّيان رِابكيشن. بوّ نمونه:

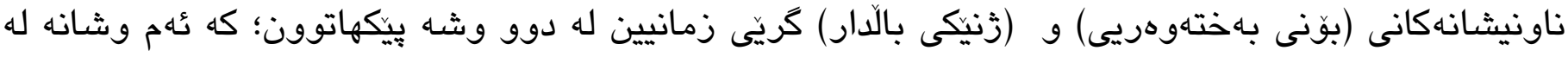

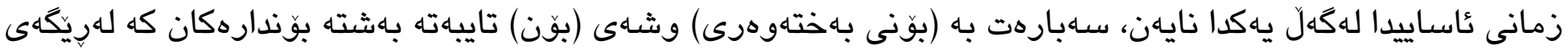

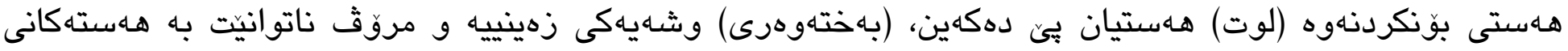

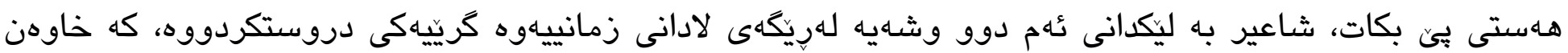

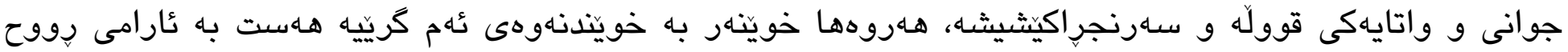

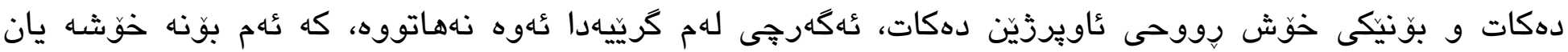

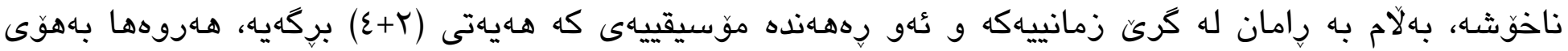

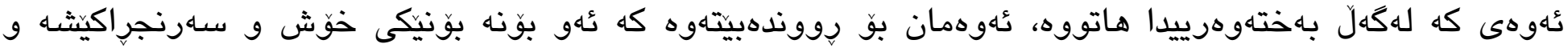

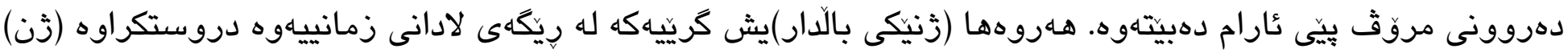
يه كيكه له دوو رهكَزهكانى مروق كه خاوهن تايبهتمهاندى ناسكى و جوانييه، لهكهليدا ئامرازى نهناسيارى (يَك) هاتووه،

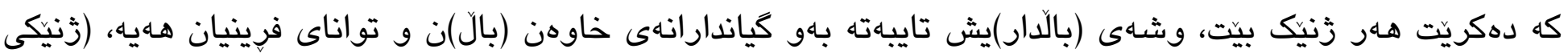

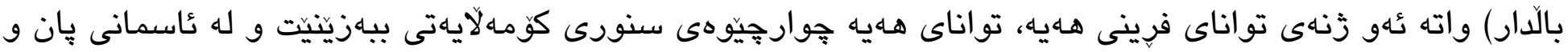

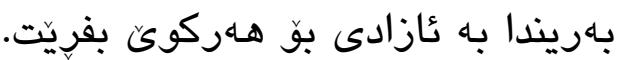

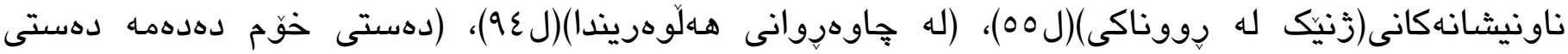

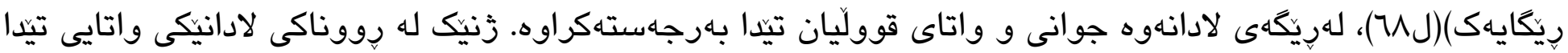
كراوه و روووناكى تايبهتمـندى ثٔهو شتانهن كه رووناكى بهخشن و مروق ئهم تايبهتمهندييهى نييه، بهلام زنيك له رووناكى دهكريّت زنيك بيت كه جوانى و ميهرهبانى و عيشق و خَّشهويستى ببهخشيت، زنيكى رووناكبير بيت و

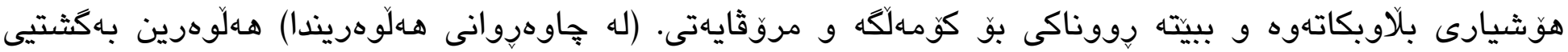
تايبهتمهنديى دار و درهخته، كه له يايزاندا كَلاكان دهوهرن و كهشيكى خهمبارانهى هونهرى و شـاعيرانه دروست 


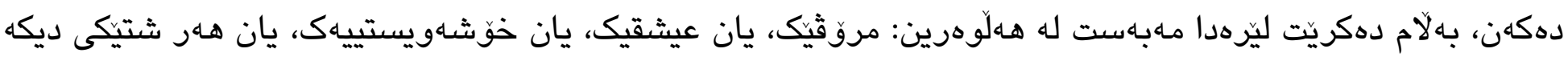

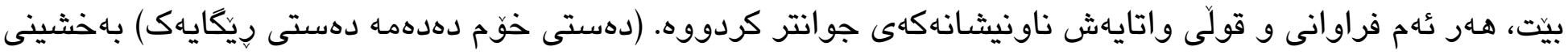
دهست به ريّكا لادانى واتاييه، كه جوانى به ناونيشـانهكه بهخشيوهو واتاكهى فراوان كردووه.

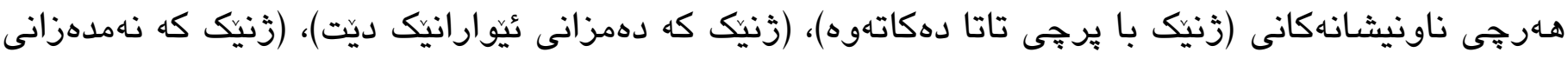

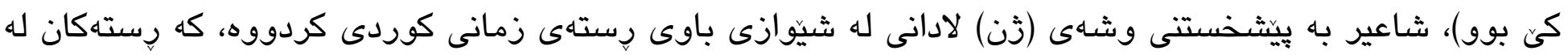
بناهرهتدا بهام شيّوهيهن:

$$
\text { زَنيك با يرجى تاتا دهكاتهيكه }
$$$$
\text { با يرجى زنيك تاتا دهكاتهوه }
$$$$
\text { من دهمزانى كه زَنيك ئيّوارانيك ديّت }
$$$$
\text { من نهمدهزانى زنيك كه كي بوو }
$$

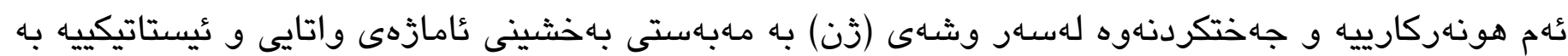
ناونيشانهكه، هـروهها دووباره ناديارى (ذّن)هكه به عامرازى نهناسيارى (يَك) تُوهندهى تر رههـنده واتاييهكهى قوول كردووهتهوه و بهمه شوانييهكى زياترى بينّ بهخشيووه و سـرنجيراكيش ترى كردووه.

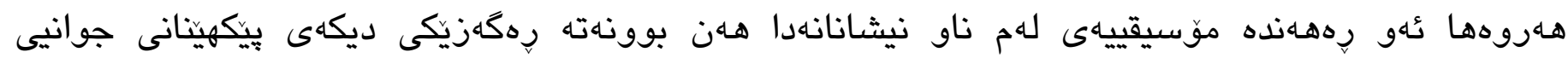
ناونيشانهكان، كه بـاهم شيوهيان:

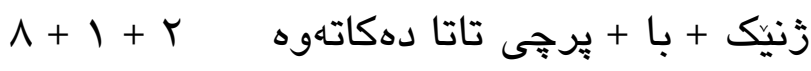

$$
\begin{aligned}
& \text { زنيك + كه دهمزانى + يُيّارانيك ديّت ب + } \\
& \text { زنيك + كه نهمدهزانى + كي بوو }
\end{aligned}
$$

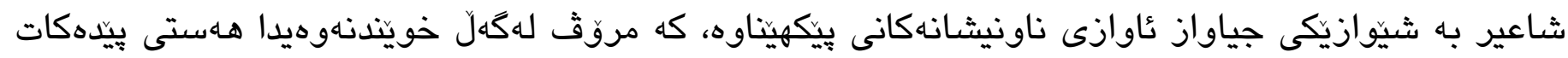

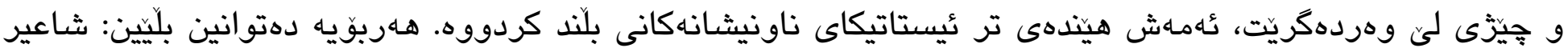

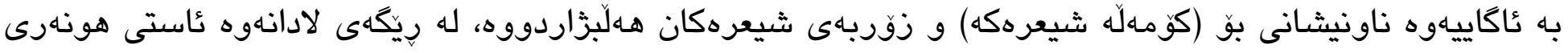

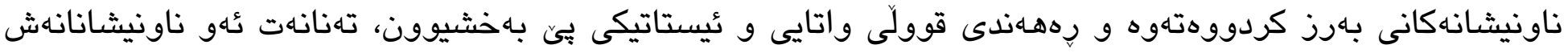

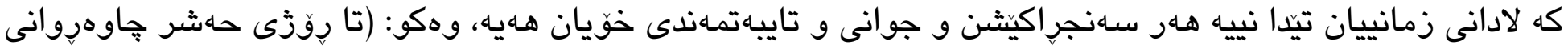

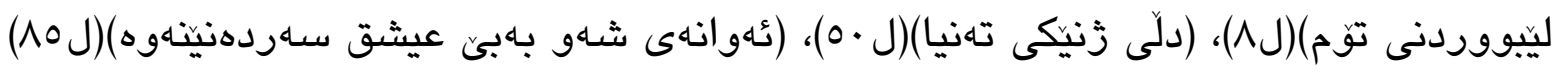




\section{تهومرى سييّله (نيستاتيكاى لادانى زمانى)}

لادانى زمانيى بريتييه له لادان له ياسا و ريّساكانى زمانى عاسايى، يهكيكه لهو بنهما هونهريانهى دهقى شيعريى، كه دهبيته رهذازيكّى كرنكى داهينان و جوانكاريى له دهقى شيعرييدا. شاعير بهمابهاست و زوّر به ورياييهوه ئهم لادانه

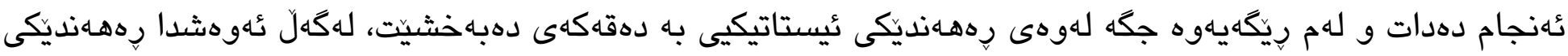

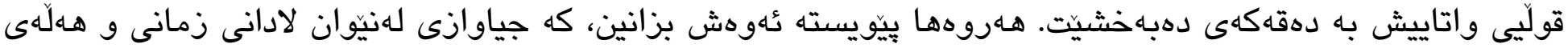

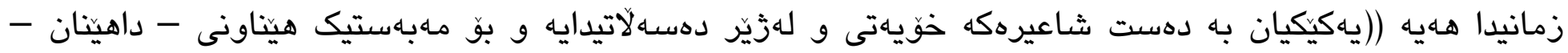

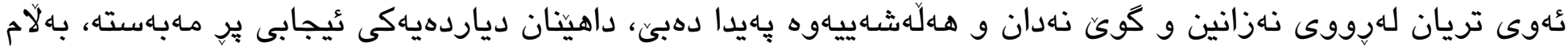

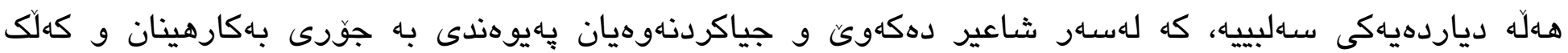

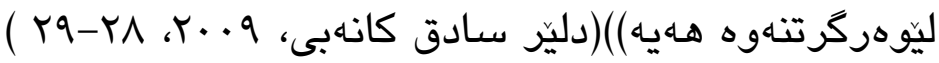

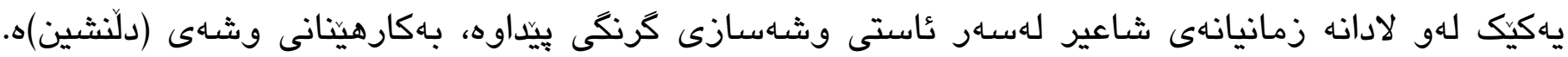

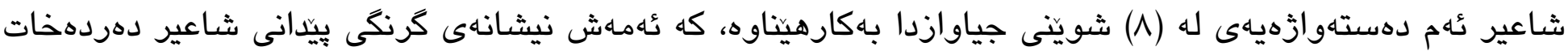
بو ئهم وشهايه.

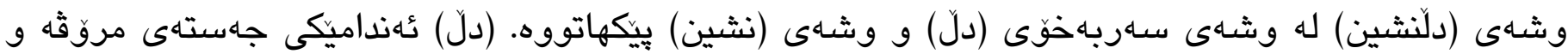

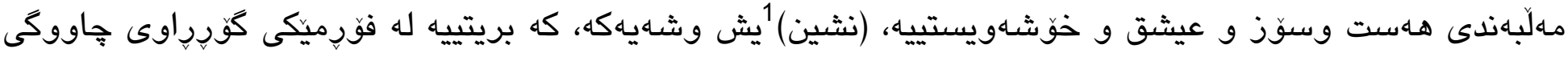

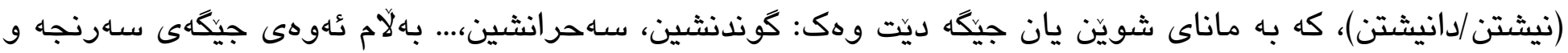

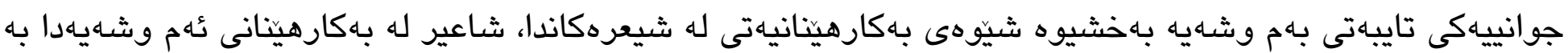
لادانيكى ترى هونهرى داهينانى كردووه، جونكه وشهكه خوىى ئامازه بو دل دهكات وهك شوينى حهوانهاهوه و كوَبوونهوهى خوّشهويستان، بهلاّم شاعير به شيّوازى جياواز بهكارى هيناوه، وهك:

$$
\text { دهنكى دلّنشين: هـاستدهكهم ئهو دهنكه دلّنشينهى ... (ل) }
$$

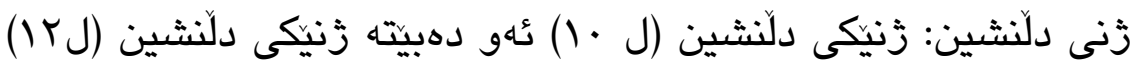

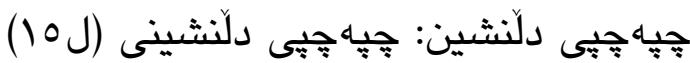
بيرهوهرى دلنشين: عئه بيرهوهرييه دلّنشينانهت (JV)

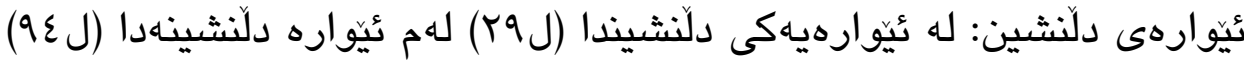




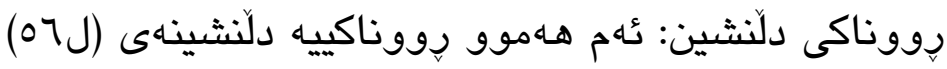

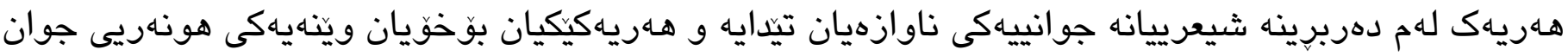

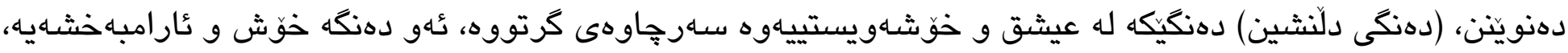

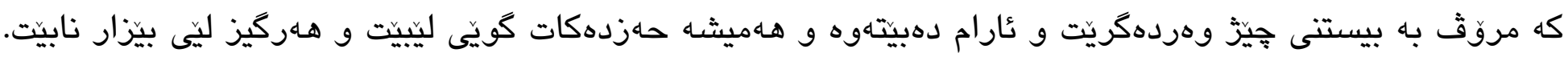

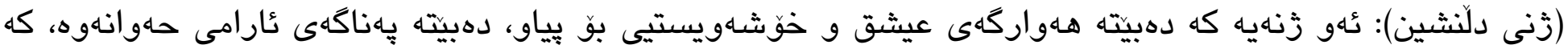

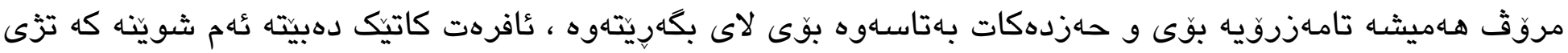

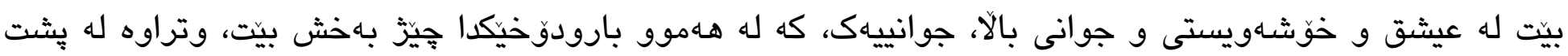

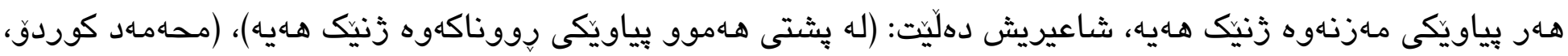

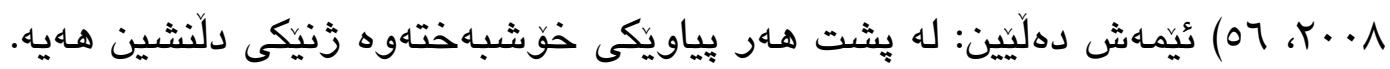

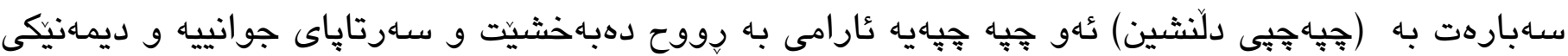

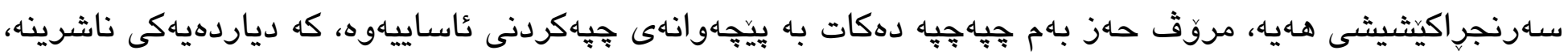

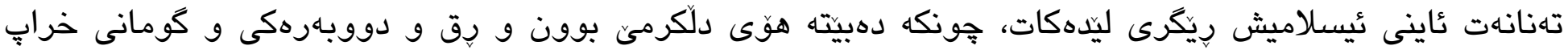
بردن. هـروهها (بيرهوهرى دلّنشين) ئهو بيرهوهرييانهن كه ساته خوّشهكانى زيانمان بير دهخهنهوه، ئهو بيرهوهريانهى

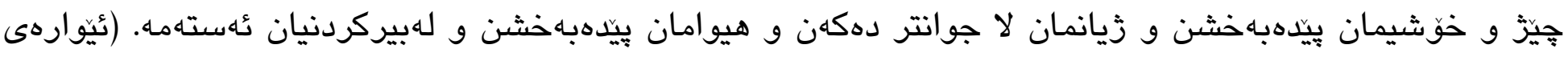

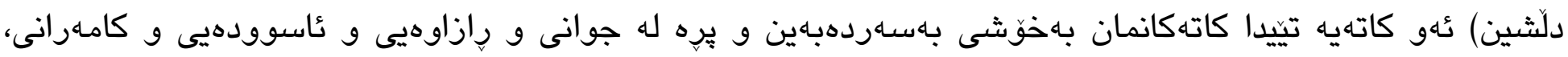

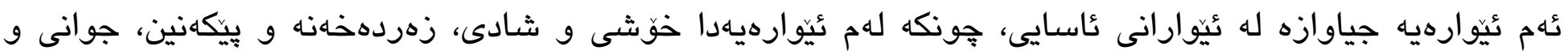

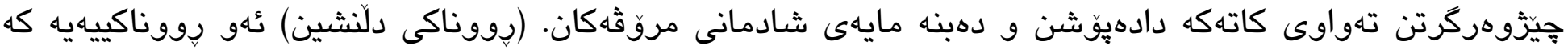
هـهيشه تهماشـاى بكهين، جهاومان تامهزروى بينينيهتى و هـهريز جاومان ئازار نادات، ئهم رِووناكييه ئاسوودهمان دهكات.

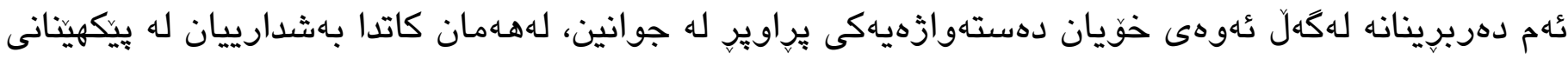

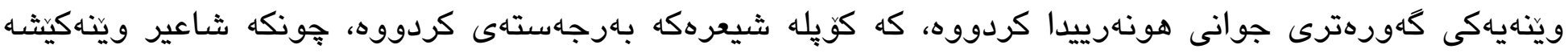

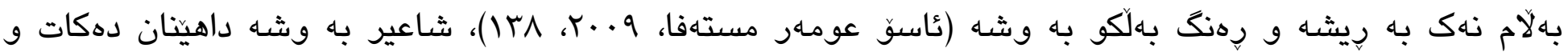
جوانييهكانمان يّيشكهش دهكات و وينّه هونهرييهكانيش رازاوهتر دهكات، بهماش زياتر توانا و دهسهلآتى شاعيرمان بو

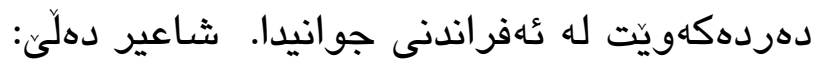
زوَرجار كه يُيِّاران دين

هـهر لهخوماهوه هـست به خهمبارييهكى زور دهكهم 
هـاستدهكهم ئهو هازه هازّه شينهى له تُاوى رووياران دىّ هـاستدهكهم ئهو دهنكُه دلّنشيناهى له لهرينهوهى داران ديى حهسرهتهكانى مروقثم بيردهخهنهوه... (Y-7)

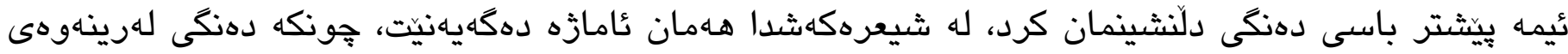

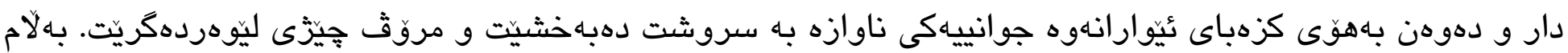

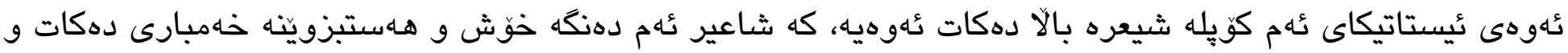

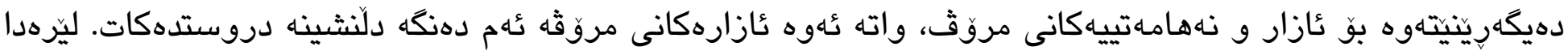

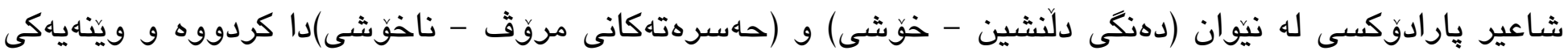
هونهرى جوانى لييان يِيكهيناوه.

هـاروهها شـاعير له شيعرى (دار)دا ديسانهوه وشـيهكى بهكارهيناوه، له فهرهـنكى زمانى كورديدا نييه، ثئويش

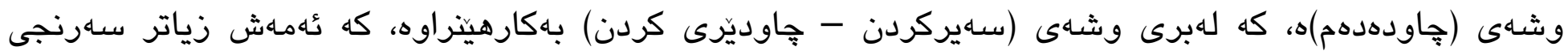

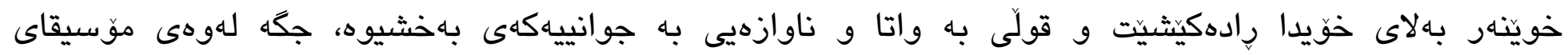
شيعرهكهشى يحن دروستكردووه. وهك دهلّيت:

لهناو هـهموو دارهكانى ئهم ولّاتهدا داريّكى نهشميل جاودهدهم دهيكهم بـ تق و لهبرى مـامكه نازهنينهكانت به كَهلا نازدارهكانى ئهو

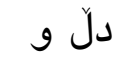

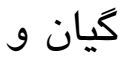

بوونم زاخاو دهدهم (ل77) 


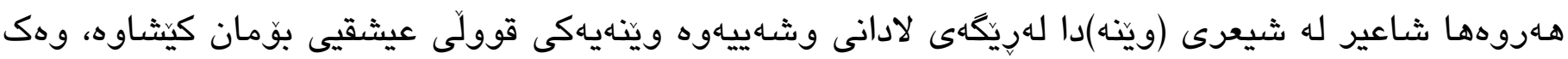
دهلّيت:

جهن خودايه جهاند خوشَها!

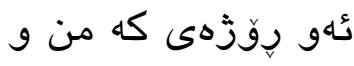
كأهو زنه كَردن كهوه

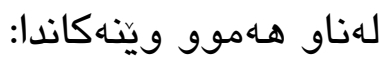
ميَزوومان تورهـلَّاوه و دهستمان له ملى يهك وهريناوه و كهرمتر له كثت بوونهوهرهكانى دنيا جووينهته باوهشى يهكهوه!! (ل r ·-Ir. ئهم كوّيله شيعره سهرهتا به دووبارهكردنهوهى دووجارى (جههند خوّشه!) جهخت لهسهر ئهوه دهاتهوه، كه به

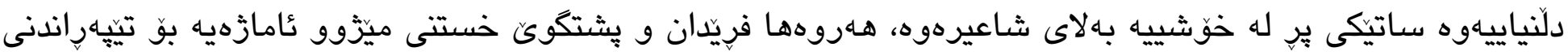

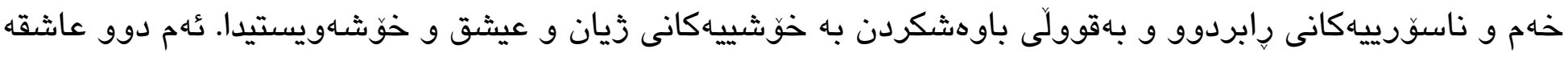

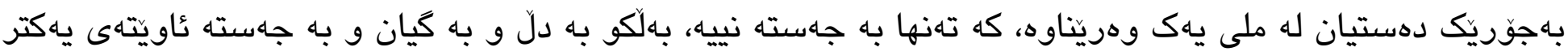

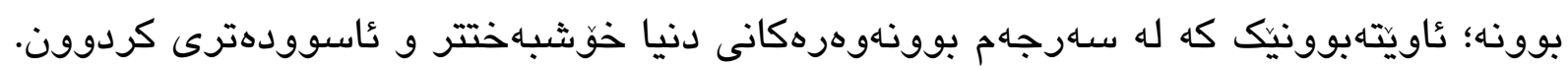
يهكيكى تر لهو لادانه زمانيانهى شاعير كرنكى بيّداوه (ياش و بِيّش خستن)ه، كه يهكيكه له هونهره ئيستاتيكييهكانى

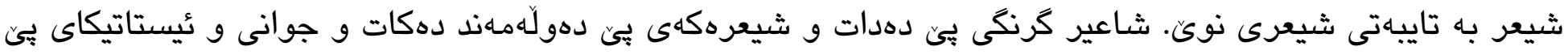

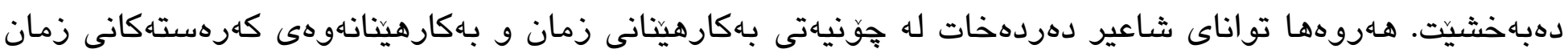

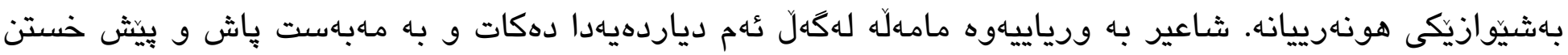
ئهنجامدهات، بو ئهوهى كونجانيكى هونهريى لهنيّوان وشه و رِّتهكاندا دروستبكات و بههايهكى ئيستاتيكى به

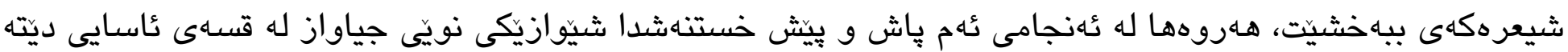

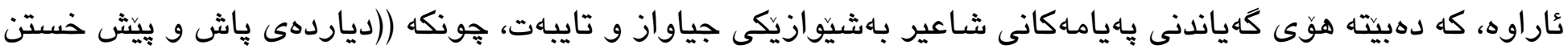


له كرنكترين دياردهكانى لادانه له يِيكهاتهى زمانيدا، كه له دهقدا ثُامانجى واتايى و ئيستاتيكى و دهروونى بهدهست

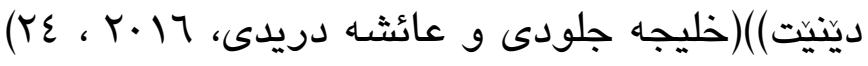

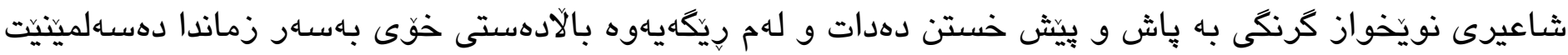

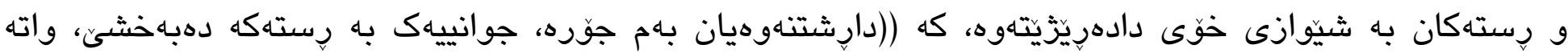

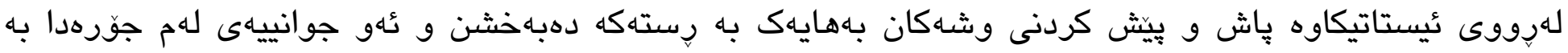

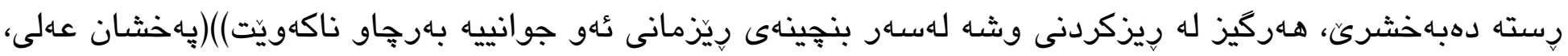

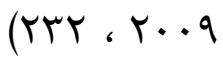

يِيشخستنى وشـه و زاراوه: يِيشخستنى وشـه يان زاراوهيهك لاى شـاعير، نيشانهى كرنكيدانى زياترى شاعيره بهو وشاهيه و جهختكردنهوهى زياتره ليَى، كه عُهمه ناوهروكى دهقهكه دهولّهمهند دهكات و دهكريت خويندنهوهيهكى جياوازى بو بكريت. شـاعير (محهمهد كوردو) لهشيعرهكانيدا ئهم جوره لادانهى بهكارهيناوه، كه بههويهوه رههـهنديكّى ئيستاتيكى و هونهريى بـه شيعرهكهى بهخشيوه، وهك لهشيعرى (له جاوهروانى هـلوهريندا) دهلِيت:

لهم ئيواره دلّنشينهاهدا

كه سروشت، دهليّى زنيكى نازهنينه

زَنيك،

دهست و يهنجنهى سهوز .. و

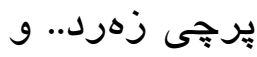

جاوهكانى شينه!(ل

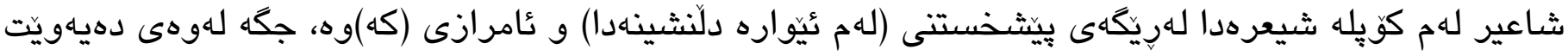

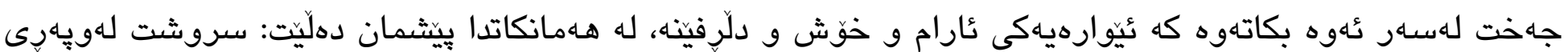
جوانيى و ناوازهيى و سـهنجراكيثيدايه، سروشت له زنيك دهيّيت له جوانيدا كهس ناتوانيت شان له شـانى بدات. ئهم يِيثخستنه بووهته هوَى ئهوهى وينته هونهرييهكه جوانتر و كيستاتيكيانهتر بيت. هـروهها شاعير لهشيعرى (ذنيك، كه

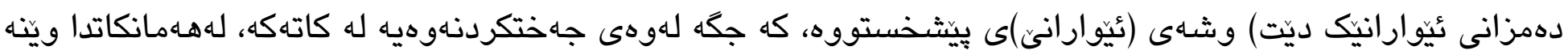
هونهرييهكهشى جوانتر كردووه، وهك دهلّيت:

ئيَّاراني، زَنيك

ديت و لهزيّر تريهى يِيِيدا 
زهمين دهجيّته نيّو خهوناهوه

زهمين له خُشَشى هاتنى تُهو

بوّنى بهاهتهوهرى

لهخويى و له هـناسهى دىّ! (ل)

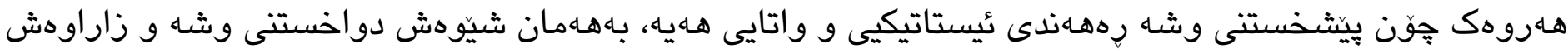

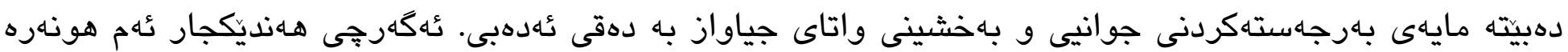

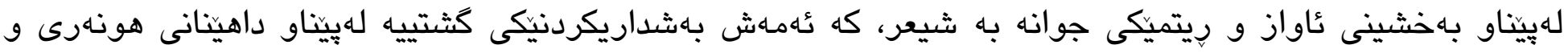

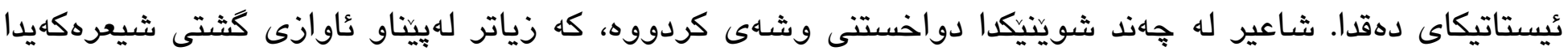

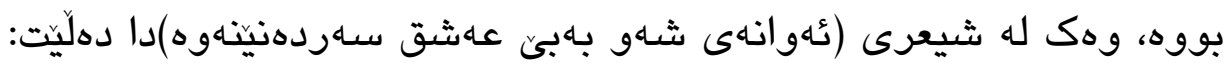
تُهى خواى مـان كُاخِّ تُهوهى بـاهبَّ عهاشق دهزى

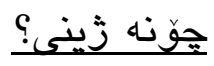
كي له شـهوانى بِي خهمدا دهست دهخاته نيّو قزييهوه و سينكى به سينگييهوه دهنوسينتي و

$$
\text { دهبيته هاوسـهرينى (ل) (1) }
$$

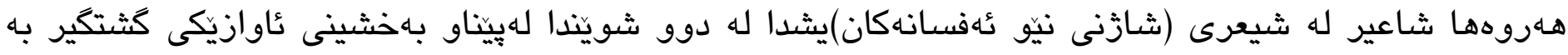

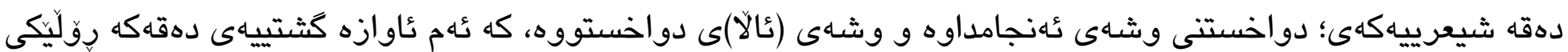
كُورهى بينيوه له بهرجاهتهكردنى ئيستاتيكاى كُشتى شيعرهكهدا، وهك دهلّيت: زنيكى جوان

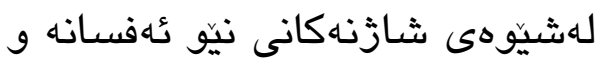
نيَّ خهون و خهيالَا 
ئهى غهمكينترين بياوى سهار ئهم كُوى زهمينه تو كه له ولَّتيكى بيَّ عَالاّ دهجِيت

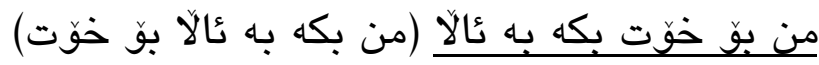
كاى من دواتر تيكَهيثتم

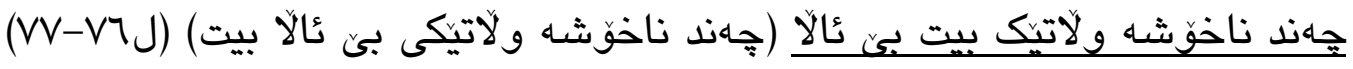
(كرتاندن)يش يهكيكه له لادانه زمانييه كاريكهرهكان، شاعير دانهيهكى زمانى يان زياتر له رسته شيعرييهكهى لا

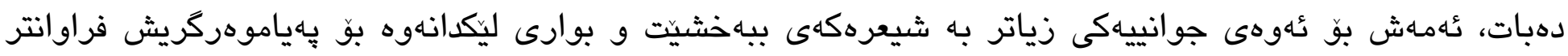

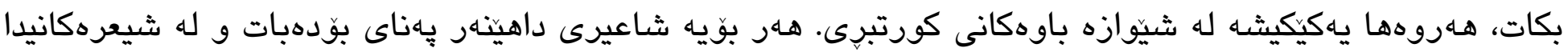
بهرجهستهى دهكات. ((جئكاى باسه دياردهى "سرينهوه - الحذف" له بيكهاتهى رستهادا دهبيته هوّى بهخشينى جوانى

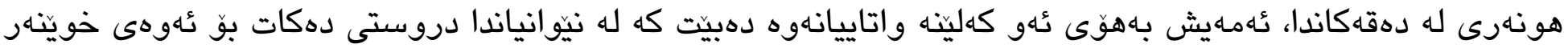

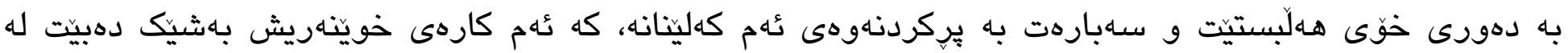

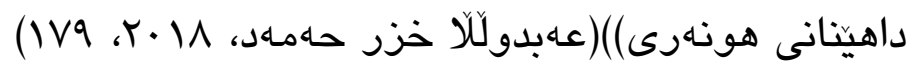
لابردنى بكهر: يهكيك له تايبهتمهندييهكانى زمانى كوردى دهرنهكهوتنى بكهره بهشيّوهيهكى راستهوخق، كه بههوى

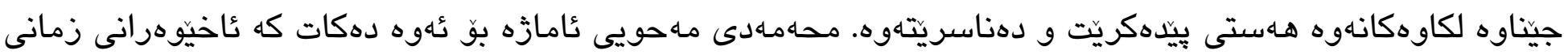

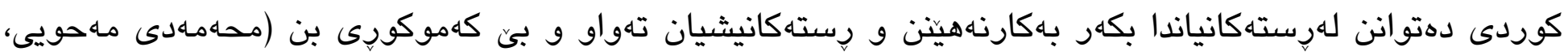

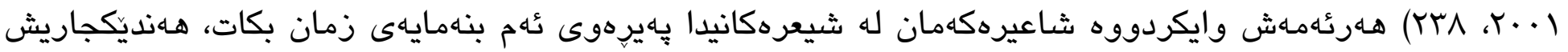

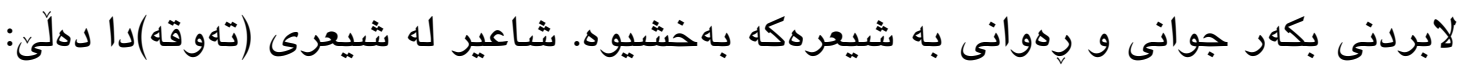

$$
\text { (تو) دهزانى كاتي تهوقه دهكهين ليّوم لهنيّو پِهنجهانمدايه و }
$$

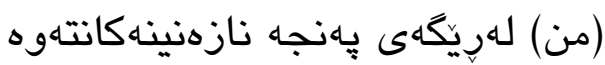

$$
\text { (من) ماجِبارانت دهكهم }
$$




$$
\begin{aligned}
& \text { (توّ) دهزانى هـهوو جارىن } \\
& \text { (من) دهستنويّزهكهت دهثكينم و } \\
& \text { (من) فيَرى نويَزَى بَّ دهسنويَزَى } \\
& \text { دلّدارانت دهكهم (ل سـ-عی) }
\end{aligned}
$$

كاتيك سـاهيرى ئهم كويله شيعرهكه دهكهين؛ دهبينين (بكهر) له حهوت جيَّه لابراوه، كاتيكيش دهيخوينينهوه (بهبئ بكهر) دهبينين وينتيهكى جوانى هونهرييه، هيج كهموكورييهكى نييه و واتاكهيشى به تهواوى كَهياندووه، ئهگَر (بكهرهكان) له شيعرهكها هاتبان؛ ثٔهوا هيج شتيكيان زياد نهدهكرد، تهنانهت له جوانى شيعرهكهيان كهدهكردهوه.

لابردنى كار: كرنكى خوّى هـيه له يِيكهينانى جوانى و ئيستاتيكاى دهقدا و زورجار شاعير به ورياييهوه ئهنجامى دهدات، جونكه لابردنى كار له زمانى كورديدا دهبيته هوَى بهخشينى سيفهتى بهردهوامى به دهقهكه، عُهمه ش لهبهرئهوهى

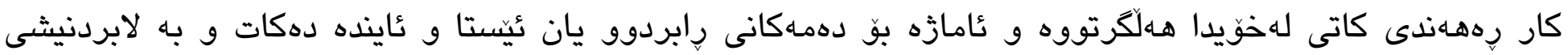
سيفهتى بـهردهوامى دهدريت بـه شيعرهكه. شـاعير دهلّي: دهبنى هـهر ئيّستا هـهتى بهاركَ خهمناكى فريدهديت لهُگلَّ مندا،

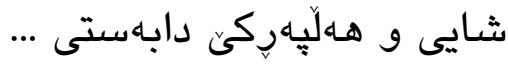

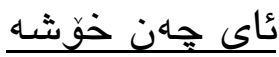

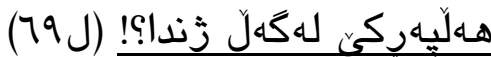

شـاعير لهم شيعرهدا يّاش ثُهوهى داواى ئهوه دهكات يِّيويسته بهركى خهموخهفهت فريّ بدريّت و دهست به زيان و

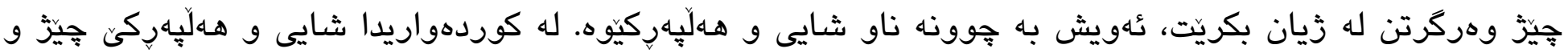

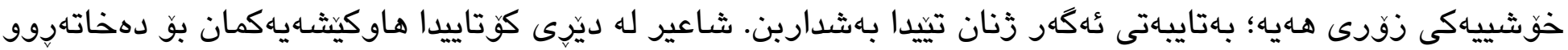

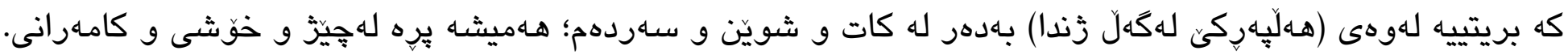
دووبارهكردنهوه يهكيكى تره له تهكنيكه كاريكَره ئيستاتيكييهكان. دووبارهكردنهوه لادانه له بنهرهتى زمانى ئاسايى و هونهريكى بـرجهاهتهردنى ئيستاتيكاى شيعره، شـاعير لهييناو جوانتركردنى شيعر و جيّكردنى ناوازيّكى ناوازه و تايبهت و ييّدانى واتايهكى قوول به دهقى شيعرهكهى يهناي بوّدهبات. دووبارهكردنهوه ((لادانيكى دهنكى و هونهريكىى 


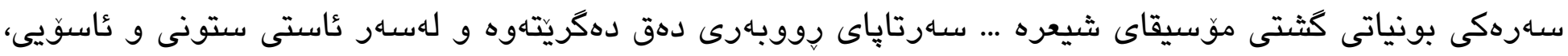

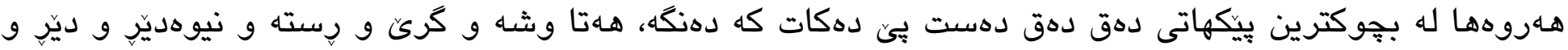

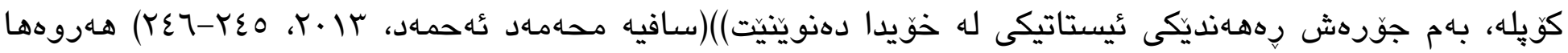

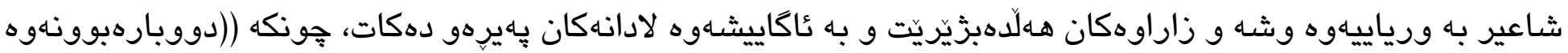

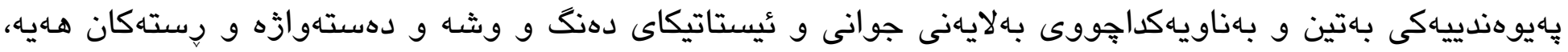

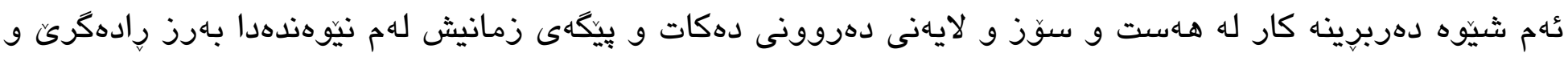

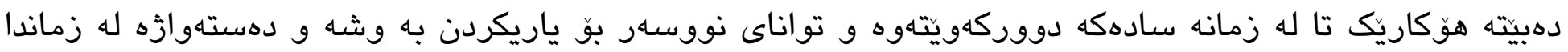

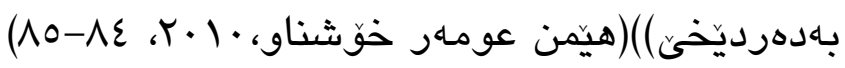

دووبارهبوونهوه له شيعرى نويدا بهيّيَى سيستهم و بهرنامـيهكى دياريكراو نييه وهك ئهوهى له شيعرى كلاسيكدا

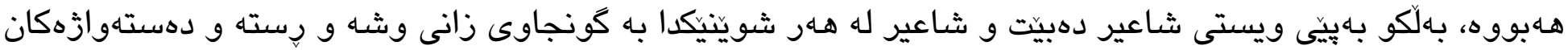

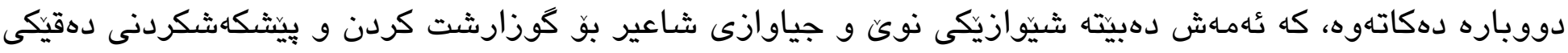

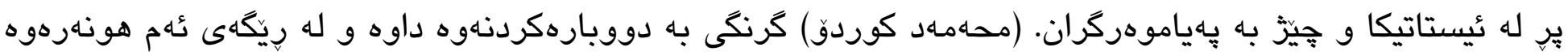
ئيستاتيكايهكى بهرزى به بهشيك له شيعرهكانى بهخشيووه. شاعير له شيعرهكانيدا جيناوى كهسى يـكهم بههـهردوو شيّوهى (سهربه خُو و لكاو)ى زورترين جار بهكارهيناوه، بهم شيّوهيهى لاى خوارهوه:

\begin{tabular}{|c|c|}
\hline زمارهى بهكارهينان & جيناوى كهسى يهكهم \\
\hline 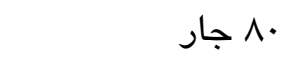 & جيّاوى كهسى يهكهمى سـهربهخو (من) \\
\hline 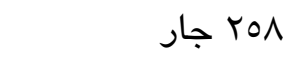 & جيناوى كهسى يهكهمى لكاو (م) \\
\hline
\end{tabular}

ئهماش ثئهوهان بوّ رِووندهكاتهوه، كه شـاعير له شيعرهكانيدا باسى لهخوّى كردووه، باسى له خوّشى و

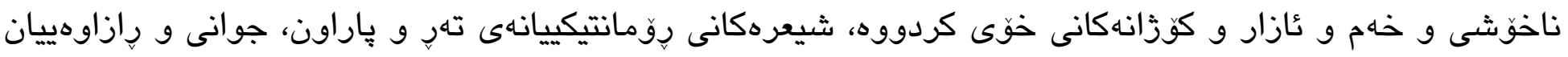
تيدايه، كوزارشتيكى داهينهارانهى هونهرييانهيه لهبارودوخى زيانى شـاعير بهتايبهتى و يياوانى كومهلكَّى كوردى

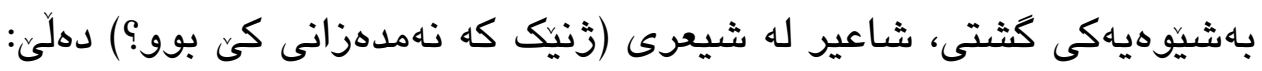

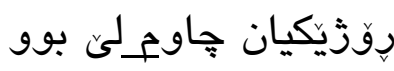
شازّنيكى نازهنين كه نه ناويم دهزانى .و نه ئاينيم دهزانى ..و 


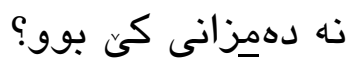

$$
\begin{aligned}
& \text { جووه دوكانى ئاوينّه فروشيككهوه } \\
& \text { من لـخوّشى ئهو زَنه } \\
& \text { زقور له خودا يِارِامـوه }
\end{aligned}
$$

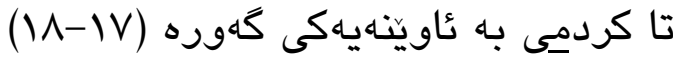

كاتيك سـاهيرى ثٔهم كوّيله شيعره دهكهين ثٔهو حهز و خوليا و ئارهزووانه دهبينين له شيعرهكها شاردراونهتهوه،

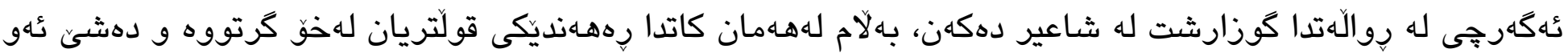

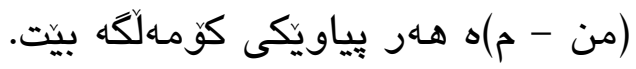
شاعير له شيعرى (ذُنيك، با يِجى تاتا دهكاتهوه)دا پازدهجار وشهى (دل)ى دووبارهكردووهتهوه: لهناو تُايِّرايهكى كُورهدا كه يِه له زاوهزاو ذَنيّكى دلّنشين هيّاى هينّى دهروا و كزهبايهكى خهمكين يֶּجָ تاتا دهكاتهوه كاتيّ بـ تهنيشتى مندا تيدّهيهرِيت وهك ئهوهى ئاكاى له دلّم بيتي كه جِوَن له خُوَشى ئهو خهريكه دهبيته ئاو جِهن جاريّك لا دهكاتهوه!

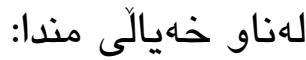


دلّى ئهو دهبيته كيزّولَهيهكى نهشميلانه

$$
\text { دلّى خَّشم }
$$

كوريزَّهيهكى قزخخاو

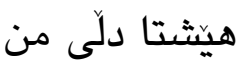

به تاواوى له دهركاى نهداوه

دلّى بيَئوقرهى ئهو، دهركا دهكاتهوه! دلّى من داواى ماتج دهكات و

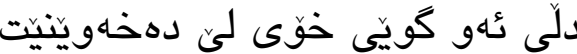
دلّى من وهكو شينيت

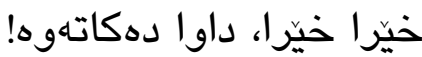
دلّى ئهو زوّر زوّر مندالآنه تا ثُهوسـاهى بهرائهت هـهلّديت لاهويَ دهترسيّت ون بيت زوّر بِه يـهله و يرتاو بـرهو لاى دلّى من رادادكاتهوه باوهش دهكهن باه يـكتردا كئمجارهيان دلّى ئهو دهبيته زَنيكى دلّنشين دلّى منيش بياوينكى داكيرساو ئهوهتانحي يُيستاش دلّى ئهو له باوهشى دلّى مندايه و 
شـاعير بهم دووبارهكردنهوهى وشـى (دل)ه جهخت لهوه دهكاتهوه كه عاشقه و به بينينى زنيك مهست بووه و كهوتووهته ناو خهيالَهو، ئهم شيعره تابلوّيهكى سـهنجيراكيثى هونهرييه، شاعير وينّهيهكى هونهرى جوان و رازاوهى

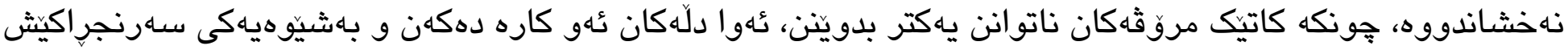

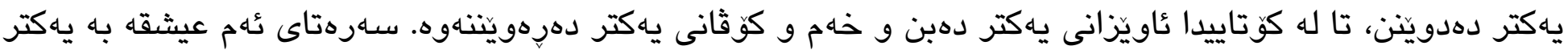

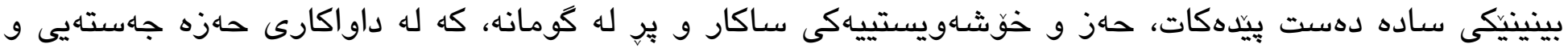

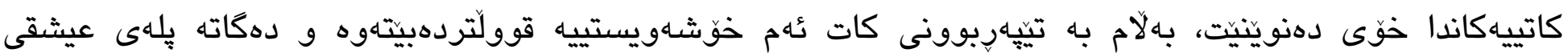

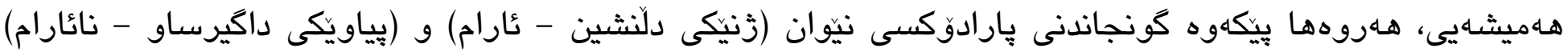
هيندهى تر تابلو هونهرييهكهى رِازاوهتر كردووه، ئهم دوو دزه ئاويَزانى يـكتر دهبن و كهشيكى يِ له ئارامى و

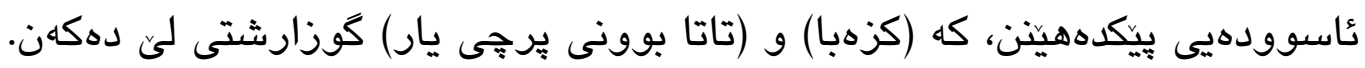

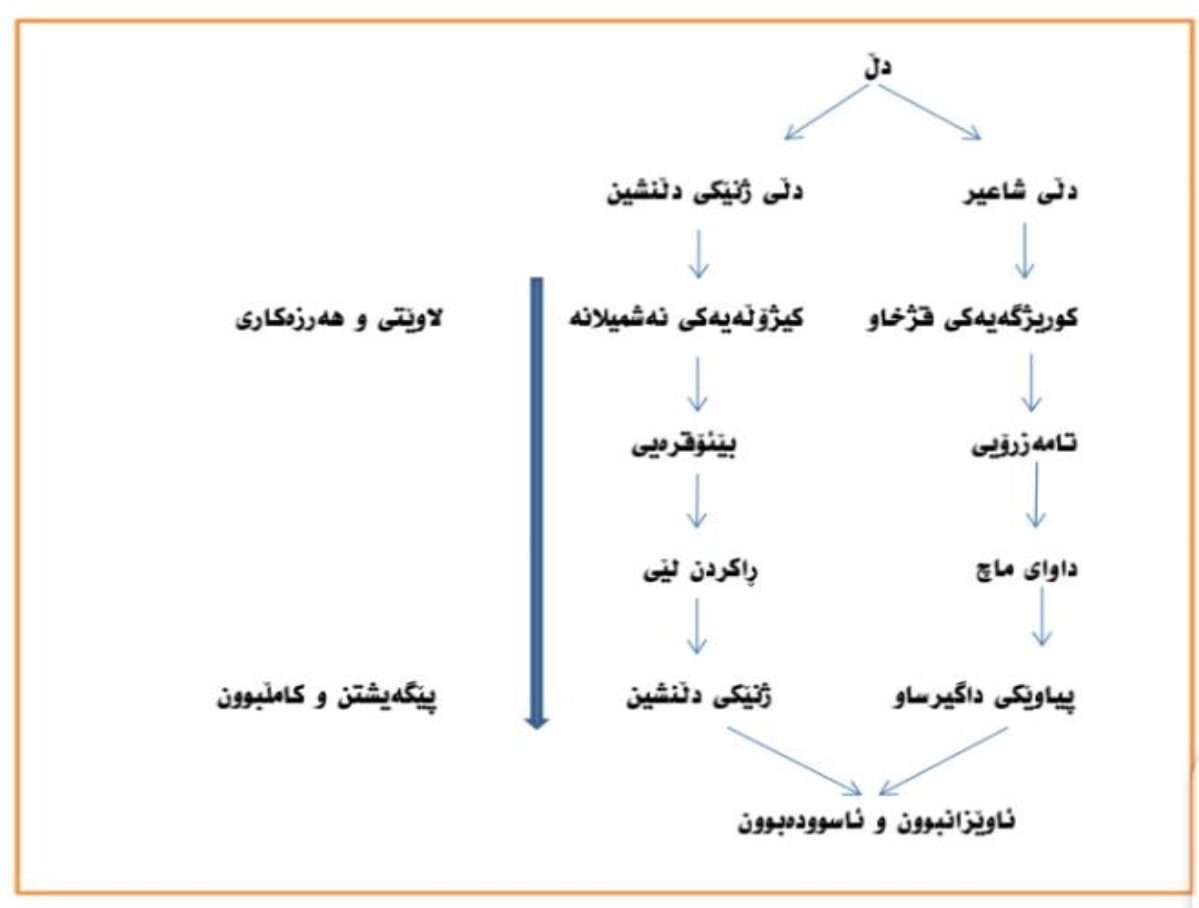

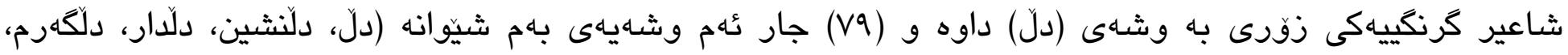
دلشكاو ) بهكارهيناوه. شـاعير به مـاهبست و به كرنكييهوه لهم وشهياهى روانيوه و جههندين دهربرينى ئيستاتيكى و ويّناهى هونهرى لحئ يِيكهينّاوه. 


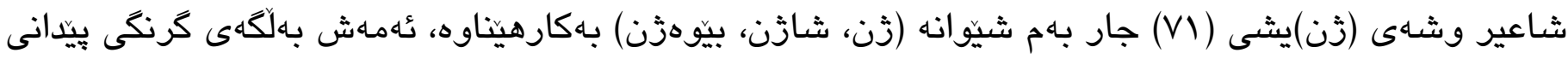

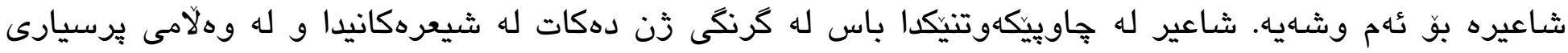

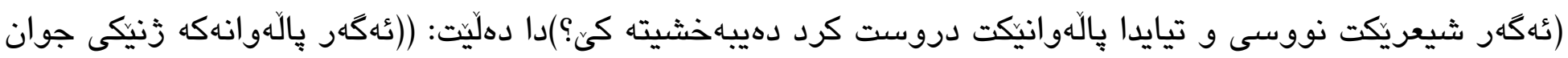

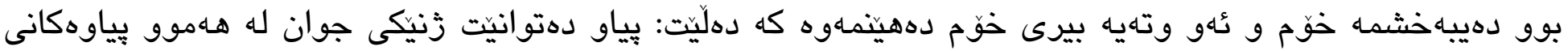

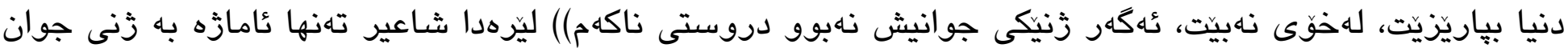

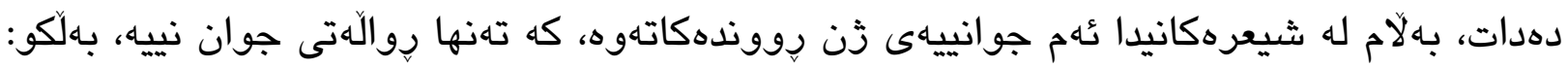

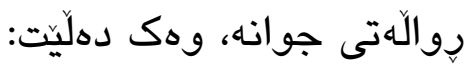
كُهى ذن كاتى مانك شهرهفى بـاراوردى،

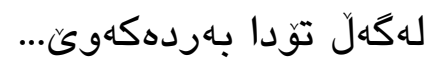
تئاو دهزيته هـهوو كيانى و با پِارجهمى شانه دهكا و زيانى لهسهر دهردهكهوى!! (ل1110) دهم به يِيكهنين و قسه شيرينه، وهك دهليّت: له ئيّوارهيهكى دلنشيندا زنيكى دهم به يِكيكنين دهستى خسته نيّو دهستمهوه و وهكو داريكيك، رِوحى رِاوشانم!(J9) دلّنهرم و ميهرهبانه، وهك دهلّيت: دلّى من جָرايهك بوو

لهناو تهنياييهكى كوشندهدا خهريكبوو دهكوزايهوه 


$$
\begin{aligned}
& \text { بهر له كوزاندنهوهى بهجهاند جركهيه } \\
& \text { دلّى ذَنيكى ميهرهبان } \\
& \text { هات به هـانايهوه (ل) } \\
& \text { يَّرَش و خهمخَرِه، وهك دهلّيت: } \\
& \text { به مندالذكهى وت: }
\end{aligned}
$$

نهكهى!

$$
\begin{aligned}
& \text { كئ دهلّي روحى يياويكّى سـهركهردان نييه } \\
& \text { له ولآتيكى يِرِ له عَازاردا } \\
& \text { كَارامى به خشَه، وهك دهلِيت: }
\end{aligned}
$$

ئيَواراني، زنيك

$$
\begin{aligned}
& \text { ديّت و لهزيّر تريهى يِيِيدا } \\
& \text { زهمين دهجيَّه نيّو خهونهوه } \\
& \text { زهمين له خوّشى هاتنى ئهو }
\end{aligned}
$$

$$
\text { بوَنى بـ ختهوهرى }
$$

لهخِيى و له هـاناسـهى ديَ! (ل17)

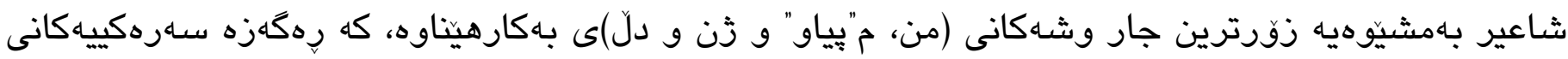

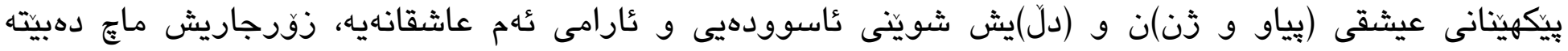

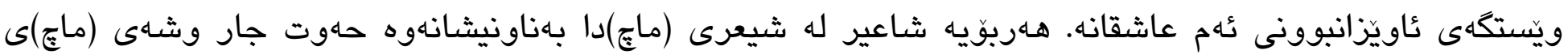

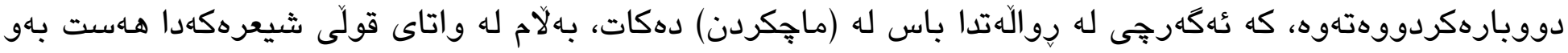




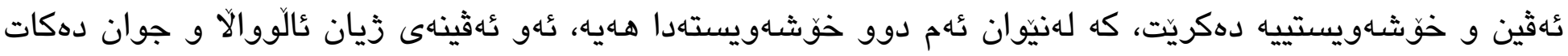

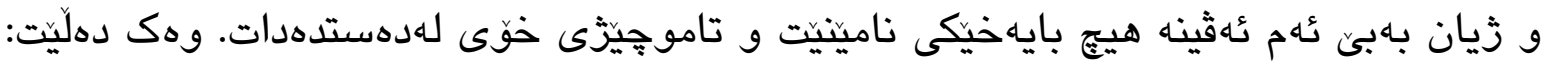

$$
\text { وتت بِّ بَّ ماجِم دهكهى؟ }
$$

وتم كوا بحّ ماجِم كردووى؟

كه ينيكهوهين

للجياتى يـك يهـ ماجِكه م

دوو دوو سيّ سنى ماجم كردووى

كه داشدهبرِيِين

باهليّى دل ماجِت دهكهم

تهنها تُهشاهو

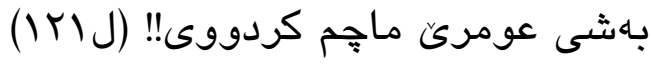

بهُشتى دهتوانين بلّيني: محهمهد كوردو زور به ورياييهوه لادانه زمانييهكانى بهكارهيناوه، هـه لادانيكى زمانيى

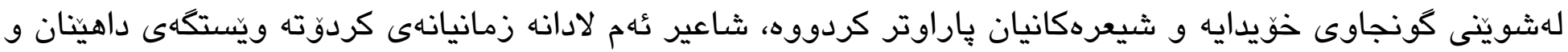
ئهر اندنى جوانيى و بـرجهاهتهردنى ئيستاتيكا، ئهو وينّاه هونهريانهى له رِيَّاهى ئهم لادانانهوه دروستكراون له لوتكهى

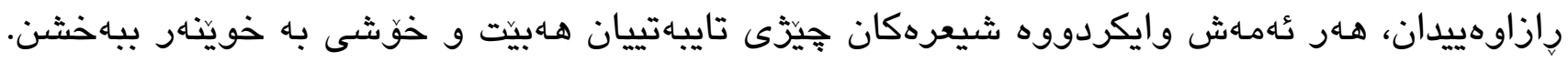




\section{ألهزجام}

له تويزّزينهوهكهماندا كَهيشتينه ئهم ئهنجامانهى خوارهوه: 1 - 1 زمانيكى تايبهت به خوّى بشتى يِيدهبهستيت، كه شاعير سهاركهوتووانه ئهم كارهى كردووه.

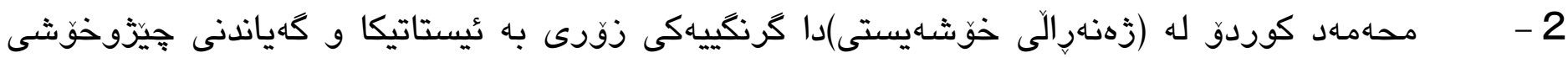
دهق داوه، بهتايبهتى لهريكّهى لادانهكانهوه.

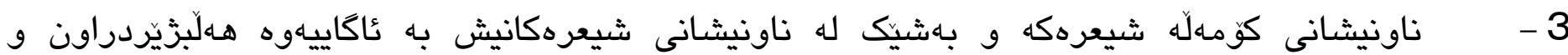

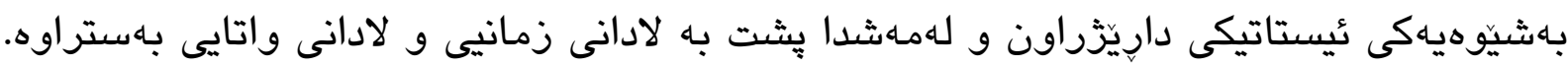

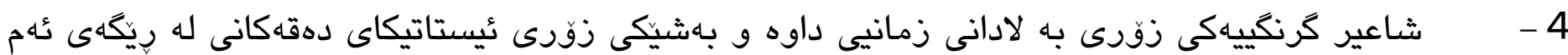
جوّره لادانهوه بهرجهسته كردووه.

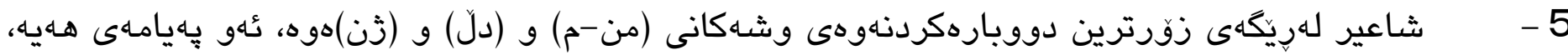

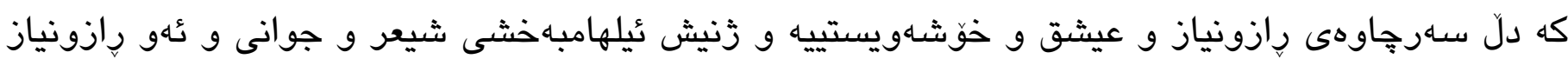
و عيثق و خوّشهاويستييهى دلّ.

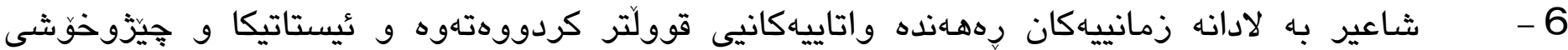
دهقهيعرييهكانيى فراوانتر كردووه. 


\title{
Language Deflected Aesthetics in the Poetry of (General Love) Muhammed Kurdo
}

\author{
Aso Omer Mustafa \\ Department of Kurdish, College of Education and Language, Charmo University , Chamchamal, \\ Kurdistan Region, Iraq. \\ E-mail: aso.omar@charmouniversity.org
}

\begin{abstract}
:
Aesthetic is main sort of poetry, during the history the poems have focused on it and in term of concrete this they have tried a lot. Some of the detractors to evaluate the poetry texts they concrete the aesthetic.

in this aspect our paper (Deflected aesthetics in the poetry of general love Muhammed Kurdo) it will attempt to illustrate those language deflected that have been concreted in his poetries.

the research consists of three pivots. The first pivot (poetry's deflected aesthetic) in general, it describes the concept of aesthetic, poetry, language, deflection and their relation to the construction of text aesthetic. The second pivot (heading aesthetic) this part describe the title aesthetic that have been concreted thru deflect. The third pivot (language deflected aesthetic) language deflected and those aesthetic dimensions in the texts have been described.

the result demonstrated in some points with the references.
\end{abstract}

Keywords: Aesthetic, Beauty, Deflection, Language Deflection, Word Deflection. 


\section{سلهجاومكان}

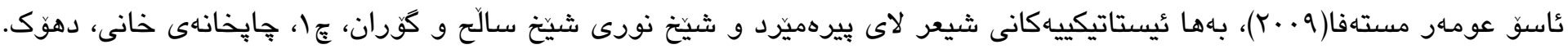

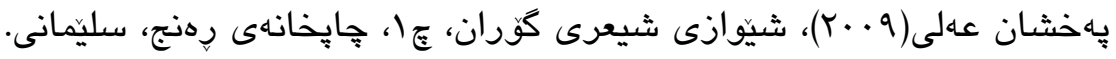

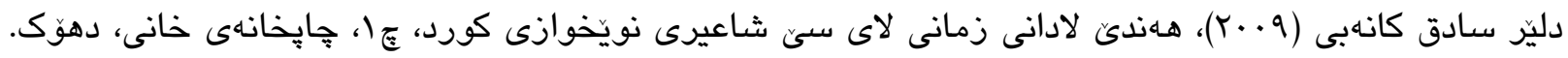

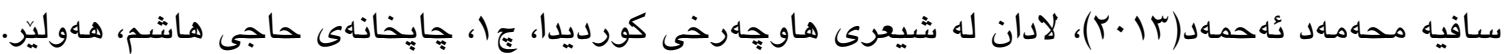
عهبلقادر حهمهئهمين محهمهد، بنياتى كارنامهيى له دهقى نويّى كورديدا، ج)، جإِخانهى تيشك، سليمانى.

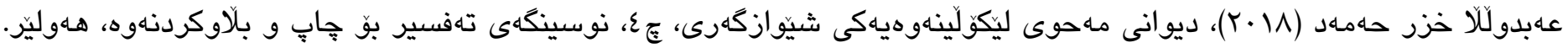

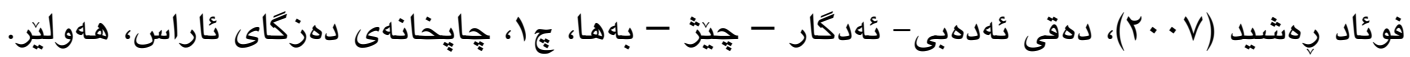

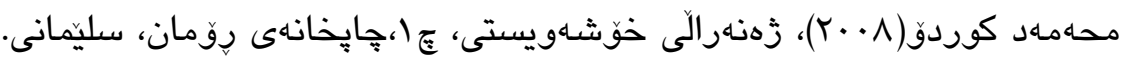
محهمهدى مه حويى( +.ب)، رِتهسازى كوردى، زانكوى سليمانى. سليمانى.

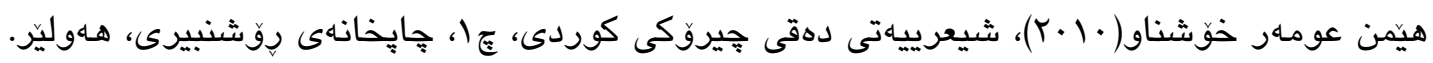

خليجة جلودي - عائشه دريدى(17 (Y) ، جماليات الانزياح في قصيدة لا أريد لهذي القصيدة أن تتتهى لمحمود درويش، رسالة ماجستير، جامعة البويرة ، الجزائر. نور الدين السد، الأسلوبية وتحليل الخطاب، جا، دارهومة للطباعة والنشر والتوزيع، الجزائر. 